\title{
Study on Effectiveness of School Leaders in Primary Schools of Wolaita and Dawuro Zones in Southern Region of Ethiopia
}

\author{
Deribe Debella Kebede \\ Lecturer, Coordinator for Higher Diploma Program, \\ School of Education and Behavioral Sciences, WSU.
}

\author{
Endale Berhanu Demissie \\ Assistant Professor, Coordinator for the research and community service, \\ School of Education and Behavioral Sciences, WSU. \\ Tafano Ouke Labiso \\ Assistant Professor, Coordinator for Institutional Quality Enhancement, \\ School of Education and Behavioral Sciences, WSU.
}

\begin{abstract}
Effective school leader is an educational leader who promotes the success of all students by facilitating the development, expression, implementation, and stewardship of a vision of learning that is shared and supported by the school community. In light of this, this research was aimed at assessing the effectiveness of school leadership in primary schools of Wolaita and Dawuro Zones. To conduct the study a descriptive survey method was used. Samples of 7 woredas, 28 schools, 28 school leaders, 28 supervisors, 28 parent representatives, 140 teachers and 280 students were selected by simple random and purposive sampling techniques as data sources. To answer the basic questions, data were collected from groups of sample respondents through questionnaires, interview and document analysis. The data were analyzed using descriptive statistical techniques including means grand means and percentages. The results of the study revealed that the school leaders were effective in managing non instructional activities which were also reflected in teachers' performance. Moreover, leaders' effectiveness in enhancing students learning was found to be medium. Thus the organization of cluster training centers, in service training, experience sharing and focus on instructional tasks in planning documents are among recommendations.
\end{abstract}

Key Terms: Effectiveness, Leadership, Educational leadership, Performance, Primary Schools

\section{INTRODUCTION}

School leaders are considered the most important person in ensuring the effectiveness of the school and efficiency in running the school (Williams 2008). The statement remarks the accountability of the leaders or principals in managing school as an educational institution in nurturing students, instilling the values of community while at the same time adjusting the demands of the present that is the mission of education Policy. Researchers in the area of school leadership concluded that schools are effectively good as their leaders (Marks et al., 2003). Despite some influential work of the effective schools research, school particularly principals are urged to lead the schools with effective leadership to ensure that quality education is available and school programs are implemented successfully aligned with students' needs, national priorities and vision (Harris et al.,2004). Being the most powerful and influential individual in schools, the principal as school leader has been the focus of discussion in the initiatives to increase the effectiveness and quality of schools. 
Recent studies point to significant correlation between the effective leadership with school effectiveness and student achievements (Williams, 2008; Leithwood etal. 2008). Earlier studies also concluded that some leaders are more effective than others (Wong et al. 1998). However, to date, past research provided very little data about the characteristics, skills, knowledge and dispositions, motivations that characterize on what the ideal attributes of the effective school leaders. Harris et al. (2004) pointed that majority of empirical studies that were conducted in developing countries does not list detail description and comprehensive understanding of the attributes and positions of effective school leaders. They also argued that positions in the school should be defined in terms of results expected and such positions should be arranged so that work would be carried out with maximum effectiveness so as to provide the desired quality education to pupils.

In Ethiopia, almost a decade is elapsed since the country strongly involved by putting hardly acquired resources on schools so that quality education is available for learners. In south region too every effort has been made to realize this ambition. So far the regional government goes on further from identifying best practices and experiences from various national and international educational institutions to implementing them contextualizing to local situation (Ministry of Education,2011). As it is on the top of national agenda and policy priority, the concern for quality education has already become homework for educational management at all levels. Wolaita and Dawro are also part of it.

Besides, the two zones have come to realize that effective leadership is one of determinant factor for effective schools which is capable of delivering quality education. As the need assessment documents done by educational planning and management reveals, the degree of commitment, capacity and motivation of school leaders to effectively and efficiently manage the three basic tasks of school leadership are found to be not up to the level required. These are ensuring the performance level of pupils, the level of teachers' performance and level of principals' effectiveness. Moreover, the slow pace in attaining quality education has been a matter of concern to management in education. In all primary schools, every member of staff has specific duties to perform. How these duties are performed leaves much to be desired. It is pertinent therefore to ask the question how primary schools in two zones effectively managed. Considering this question, the problem of this study is to determine how effective the leaders of primary schools in Wolaita and Dawuro zone, has been in providing quality education for children attending primary education. In addressing this problem, the following research questions were raised.

1. To what extent school leaders are effective in discharging their leadership role in primary schools in Wolaita and Dawro zones?

2. How effectively do school leaders manage teachers to perform their teaching and learning activities in primary schools in two zones in question?

3. To what extent school leaders are effective in enhancing student learning process?

\section{Objectives of the study General Objective}

General objective of the study is to investigate the effectiveness of school leaders in managing their schools in primary schools of the two zones in the questions.

\section{Specific objectives}

1. To identify how effectively school leaders discharge their role in primary schools of study areas

2. To assess the performance level of teachers as measure of school leader in primary schools in questions 
3. To identify the effectiveness of school leaders in enhancing student learning in primary schools

\section{CONCLUSIONS}

1. The findings of the study revealed that school leaders have gaps in discharging their leadership role particularly in such competencies as preparation of planning, coordination and organization of tasks, motivation of employee, communication and modeling. These situations partly explain why improvement programs in schools are gradual and lack consistency.

2. Effective school leaders are the one who committed to enhance student learning. Pertaining to this it is found out that school leaders were effective in other school tasks than instructional activities. In other word school leaders are preoccupied with visible part of administration paying unbalanced attention to most critical aspect of school, instructional tasks. Generally speaking the effectiveness of school leaders is medium. The present problems related to student achievement, attendance, misbehavior, dropouts, repetition and stakeholders' satisfaction and even frequent changes in principal ship are due to situations mentioned above. Therefore, the school leaders' effectiveness to enhance students learning is not as it supposed to be.

3. The performance of teachers in classroom and outside classroom reflects the effectiveness of school leaders' management. As findings revealed, teachers performing well activities that are carried out outside classroom than inside the classroom. This means teachers are more effective in out of classroom tasks. These facts coincide with what has been mentioned regarding school leaders. School leaders were more effective in other school tasks so did the teachers. Moreover, the results of performance evaluation did not reflect the condition on the ground. The problems that exist in primary schools of study areas are the results of focus of school leaders in exercising their leadership

\section{DISCUSSIONS AND FINDINGS}

This section of the study deals with research methodology: research method, sources of the data, sample size sampling techniques, data gathering tools and methods of data analysis.

In the study both qualitative and quantitative methods were employed. The appropriate research designed employed in the study was descriptive-survey research design. Descriptive survey design is appropriate because it helps the researchers to collect different types of data on situation that exists, opinions that are prevailed, trends that are developed and preferences that are sought (Best and James, 2005).

In the study both primary and secondary data sources were used. Primary data were gathered from principals, teachers, supervisors, students and members of PTA. The main sources of secondary data were teachers' performance and students' grade eight results ( 2011-2013)

\section{Sample size}

The two zones are made up of 17 woredas (districts). From these ,7 woredas (districts) were selected which contains 133 schools , 251 school leaders , 901 teachers, 112 supervisors, 84 members of parent representatives and 6633 students. From the population mentioned above, taking into account the time, energy and cost of the researchers, 7 woredas (districts), 28 schools, 28 school leaders, 28 supervisors, 28 parent representatives, 140 teachers and 280 students were subject of the study. This makes the total sample size 504 . 


\section{Sampling Techniques}

For the purpose of the study 5 woredas (Kindo koisha, Damot woyde, Humbo, Boloso Sore and Ofa ) from Wolaita zone and 2 woredas (Maraq and Gena Bossa) from Dawro zone were selected using random sampling method to give equal chance for population to be selected .

Likewise, the selection of schools was through simple random sampling technique. Simple random sampling is a probability sampling procedures which give equal chance for population to be selected (Sarantakos, 2005).The main principals, cluster supervisors and representatives of parents were selected by employing purposive sampling due to the fact that they supposed to have adequate knowledge about what is going on in their respective schools. Sample teachers respondents were selected by systematic random technique from attendance lists. Students from grade 7 and 8 (five from each grades) who had been actively involved in five to one networking were included.

In the study questionnaires, interview and document analysis were used to collect pertinent data from respondents. The need for questionnaire was arisen due to the fact that it provides sufficiently valid descriptive information about the views and attitudes of the respondents (Wellington, 1996). The questions on school leadership were designed based on competencies outlined in standards recently prepared by Ministry of Education (2011) for school leaders. In the same way questions regarding teachers' performance and student learning were adopted from blue print of School Improvement Program. To convey the message clearly questionnaires were prepared in local language.

Semi structured interviews were prepared to elicit pertinent information from representatives of parents on the effectiveness of school leaders. Teachers' performance evaluation and reports on grade eight results were also assessed to see the level of teachers' performance student learning. Therefore, in sample woreda grade eight national examinations for consecutive three (2011-2013) years were used.

Data gathered through questionnaire, interview and document were analyzed quantitatively and qualitatively. Qualitative data were carefully studied, categorized and combined to describe the items as expressed by the respondents and as understood by the researchers. Quantitative data obtained through questionnaires and documents which are were coded, tabulated, organized and treated with descriptive statistical techniques for analysis. In doing so, due consideration was given to satisfy the basic questions raised and the objectives of the study set. Percentages, means and grand means were used.

Pertaining to Sex the above table shows that 32,21 and 44.6 percent of the respondents were female school leader, supervisor and students respectively. These figures indicated the increasing involvement of females in school management and enrollment. Besides, when one happens to refer to the age he/she recognizes that young work force begins to influx into the education system. The interesting improvement in connection with this is that 76.4 percent of students in catchment areas were attending their primary education at their right age.

In regard to qualification 25, 59 and 9 percent of school leaders, supervisors and teachers were degree holders which imply how much the government committed to bring quality to the sector by upgrading teachers' education level. The majority (100 percent of school leaders and supervisors and 75 percent of teachers) were also served more than four years which can put them in a position to describe the effectiveness of leadership in their respective schools. 


\section{EFFECTIVENESS OF SCHOOL LEADERS IN DISCHARGING LEADERSHIP ROLE}

One of the measures of the effectiveness of school leaders are their ability in discharging and exercising competences expected of them. Pertaining to this, respondents (teachers and supervisors) were asked to give their opinions and the following responses were obtained.

The effectiveness of school leader depends up on how clearly and measurably activities are planned for future use. In response to the question regarding school leaders competence for preparation of planning and leading their followers to common goal both teachers and supervisors were uncertain about the competencies with computed mean value 3.21 and 3.36 respectively. This shows that leaders have a gap in preparing and rallying employees behind them to achieve organizational goals.

Respondents were also asked whether school leaders carry outs activities in coordinated manner. The figure in Item 2 and 3 of the table 2 below indicated though both respondents had the same stance, teachers were more unsure $(\mathrm{m}=2.8$ and 3.08$)$ than supervisors $(\mathrm{m}=3.07$ and 3.21). From this it is possible to say that activities are not well organized and coordinated to achieve the various objectives being set.

Table 1 Response on leaders' effectiveness in discharging leadership role

\begin{tabular}{|c|c|c|c|c|}
\hline No & Descriptions of competencies & Respondents & $\mathrm{N}$ & Mean \\
\hline \multirow[t]{2}{*}{1} & \multirow[t]{2}{*}{ Ability to prepare plan that lead school community to common goal } & Teachers & 140 & 3.21 \\
\hline & & Supervisors & 28 & 3.36 \\
\hline \multirow[t]{2}{*}{2} & \multirow[t]{2}{*}{ Ability to organize activities } & Teachers & 140 & 2.80 \\
\hline & & Supervisors & 28 & 3.07 \\
\hline \multirow[t]{2}{*}{3} & \multirow[t]{2}{*}{ Ability to lead activities in coordinated way } & Teachers & 140 & 3.08 \\
\hline & & Supervisors & 28 & 3.21 \\
\hline \multirow[t]{2}{*}{4} & \multirow{2}{*}{$\begin{array}{l}\text { Ability to motivate teachers \&other employees So that they used their } \\
\text { knowledge\& skills effectively }\end{array}$} & Teachers & 140 & 2.32 \\
\hline & & Supervisors & 28 & 3.37 \\
\hline \multirow[t]{2}{*}{5} & \multirow[t]{2}{*}{ Ability to control school activities } & Teachers & 140 & 3.54 \\
\hline & & Supervisors & 28 & 3.60 \\
\hline \multirow[t]{2}{*}{6} & \multirow{2}{*}{$\begin{array}{l}\text { Ability to evaluate the performance of school activities based on } \\
\text { evidences }\end{array}$} & Teachers & 140 & 3.22 \\
\hline & & Supervisors & 28 & 3.78 \\
\hline \multirow[t]{2}{*}{7} & \multirow{2}{*}{$\begin{array}{l}\text { Ability to make decision by searching alternatives and participating } \\
\text { others }\end{array}$} & Teachers & 140 & 3.15 \\
\hline & & Supervisors & 28 & 3.60 \\
\hline \multirow[t]{2}{*}{8} & \multirow{2}{*}{$\begin{array}{l}\text { Ability to communicate and work with people within and without } \\
\text { school }\end{array}$} & Teachers & 140 & 2.85 \\
\hline & & Supervisors & 28 & 3.32 \\
\hline \multirow[t]{2}{*}{9} & \multirow[t]{2}{*}{ Report financial performance on time for stakeholders } & Teachers & 140 & 4.04 \\
\hline & & Supervisors & 28 & 4.0 \\
\hline \multirow[t]{2}{*}{10} & \multirow[t]{2}{*}{ Modeling for others } & Teachers & 140 & 3.05 \\
\hline & & Supervisors & 28 & 3.18 \\
\hline \multirow[t]{2}{*}{11} & \multirow[t]{2}{*}{ Ability to lead quality package with knowledge and understanding } & Teachers & 140 & 2.7 \\
\hline & & Supervisors & 28 & 3.2 \\
\hline \multirow[t]{2}{*}{12} & \multirow{2}{*}{$\begin{array}{l}\text { Effort to equip the school with necessary resources that support } \\
\text { learning processes }\end{array}$} & Teachers & 140 & 3.66 \\
\hline & & Supervisors & 28 & 4.04 \\
\hline \multirow[t]{2}{*}{13} & \multirow[t]{2}{*}{ Ability to accept changes and new way of doing things } & Teachers & 140 & 3.25 \\
\hline & & Supervisors & 28 & 3.33 \\
\hline \multirow[t]{2}{*}{14} & \multirow[t]{2}{*}{ Work focusing on result and stakeholders interest } & Teachers & 140 & 3.05 \\
\hline & & Supervisors & 28 & 3.10 \\
\hline
\end{tabular}

4.50-5.00 $=$ strongly agree, 3.50-4.49= Agree, 2.5-3.49= Undecided 1.5-2.49= Disagree, $1.00-$ $1.49=$ strongly disagree

In response to controlling school the activities (item 5) both respondents were agreed (teachers $\mathrm{m}=3.54$ and supervisors $\mathrm{m}=3.6$ ) that leaders did this role well. Thus possibly 
leadership in schools is control -oriented. Evaluation of teachers' performance and participatory decision making are one of the major part of school leadership. In both aspects teachers were uncertain with computed mean value 3.22 and 3.15 while supervisors agreed that school leaders made evaluation $(\mathrm{m}=3.78)$ based on evidences and made decisions by participating teachers $(m=3.60)$. This may show that school leaders have not been transparent and allow teachers in the process of decision making as the supervisors may think.

The degree of communication among members of educational organization is one competence a school leader should have. In this regard teachers $(\mathrm{m}=2.8)$ and supervisors (3.32) were unsure whether school leaders had this competency or not. This indicates that the school leaders have a gap in communication which is vital to win the support of school community to achieve school missions.

In item 9 respondents were asked whether school leaders present the financial performance of the school on time to stakeholders. Both respondents agreed with almost the same mean $=4.00$. From this with one can conclude that school leaders by reporting the financial performance to the stakeholder they could retain the support for future. The appropriate usage of finance by leaders confirmed by responses given to questions (item 12) whether they made an effort to equip schools with resources. As responses show both teachers (3.66) and supervisors (4.04) agreed that leaders were strived to equip schools with necessary resources. Thus it is possible to say that school leaders were using scarce resources to the activities listed in the plan.

In response to questions such as being model for other (item 10) and leading quality package with knowledge and understanding (item 11) both teachers ( $m=3.05$ \&3.18) and supervisors $(\mathrm{m}=2.7 \& 3.2)$ were uncertain that their leaders are a good model and lead quality package with knowledge and understanding. From this one can say that the main reason why improvement in schools has been gradual and selective.

In regard to the questions whether school leaders accepted change and new way of doing things (item13) and work focusing on result (item 14) the respondents were not sure with computed mean value ranging from 3.10- 3.33. From this it is possible to say that the school leaders have not been change resistant but subjective in measuring the outcome. The later behavior could affect school improvement and development.

The data obtained from the parent representatives through the interview confirmed that the majority of school leaders were increasingly improving from time to time. According to respondents some are good in managing teaching learning, others in creating good rapport with stakeholders and the rest in handling financial issues. The majority of school leaders interviewed also ascertained that they had a gap in the area of planning and implementing them, motivating teachers and leading instructional aspects than non instructional activities.

\section{TEACHERS PERFORMANCE AS MEASURE OF SCHOOL LEADERSHIP EFFECTIVENESS}

The performance level of the teachers as perceived by the students can tell something about the effectiveness of school leaders. Here teachers' activities are categorized into two as instructional activities that taking place with in classroom and outside the classroom. To this effect, students were questioned and the following data secured. 
Table 3 Students responses on teachers' performance in the classroom activities

\begin{tabular}{|c|c|c|c|c|c|c|c|c|c|c|c|c|}
\hline \multirow[t]{3}{*}{ No } & \multirow{3}{*}{$\begin{array}{l}\text { Item describing teachers } \\
\text { performance in classroom }\end{array}$} & \multicolumn{11}{|c|}{ Alternatives } \\
\hline & & \multicolumn{2}{|c|}{ SA } & \multicolumn{2}{|c|}{ A } & \multicolumn{2}{|c|}{ UD } & \multicolumn{2}{|c|}{$\bar{D}$} & \multicolumn{2}{|c|}{ SD } & \multirow[t]{2}{*}{ Mean } \\
\hline & & $\mathrm{F}$ & $\%$ & $\mathrm{~F}$ & $\%$ & $\mathrm{~F}$ & $\%$ & $\mathrm{~F}$ & $\%$ & $\mathrm{~F}$ & $\%$ & \\
\hline 1 & $\begin{array}{l}\text { Adequately prepared \& delivered } \\
\text { the subject they taught }\end{array}$ & 95 & 33.8 & 49 & 17.5 & 79 & 28.4 & 27 & 9.5 & 30 & 10.8 & 3.54 \\
\hline 2 & $\begin{array}{l}\text { Use appropriate teaching } \\
\text { methodology }\end{array}$ & 68 & 24.4 & 34 & 12 & 53 & 18.8 & 96 & 34.5 & 28 & 10 & 2.31 \\
\hline 3 & $\begin{array}{l}\text { Motivate learners to question \& } \\
\text { answer without fear }\end{array}$ & 26 & 9.2 & 43 & 15.4 & 116 & 41.5 & 78 & 27.7 & 4 & 6.2 & 2.94 \\
\hline 4 & $\begin{array}{l}\text { Provide learning support based on } \\
\text { sex \& learning differences }\end{array}$ & 46 & 16.5 & 69 & 24.7 & 105 & 37.6 & 46 & 16.5 & 14 & 4.7 & 3.31 \\
\hline 5 & $\begin{array}{l}\text { Covered their subject at the right } \\
\text { time }\end{array}$ & 80 & 28.6 & 91 & 32.5 & 19 & 6.8 & 83 & 29.6 & 7 & 2.5 & 3.54 \\
\hline 6 & $\begin{array}{l}\text { Assess, evaluate and provide } \\
\text { feedback to the learner immediately } \\
\text { to see their progress }\end{array}$ & 22 & 7.9 & 51 & 18.4 & 118 & 42.2 & 81 & 28.9 & 8 & 2.6 & 2.99 \\
\hline 7 & $\begin{array}{l}\text { Give tasks that engage students in } \\
\text { class }\end{array}$ & 16 & 5.8 & 65 & 23.1 & 102 & 36.5 & 59 & 21.2 & 38 & 13.5 & 2.86 \\
\hline 8 & $\begin{array}{l}\text { Support instruction with teaching } \\
\text { materials }\end{array}$ & 40 & 14.3 & 170 & 60.7 & 70 & 25 & - & - & - & - & 3.89 \\
\hline
\end{tabular}

4.50-5.00 = strongly agree, 3.50-4.49= Agree, 2.5-3.49= Undecided 1.5-2.49= Disagree, $1.00-$ $1.49=$ strongly disagree

The performance of teachers is one of the measures of the effectiveness school leadership. Students are the closest customers who can tell us how effectively the teachers were managed to effectively perform their teaching learning activities. In response to the question whether the teachers use appropriate teaching methods that enhance student learning $(=2.31)$ ,motivate them to ask questions and give answers $(=2.94)$, provide support based on sex and learning difference $(=3.31)$, assess, evaluate and provide feedback to the learner immediately to see their progress(2.99) and engaging students in classroom $(=2.86)$ the computed mean values on each issues confirmed that the students had doubts to agree or disagree. On the other hand, the students were agreed regarding questions such as adequate preparation of lessons $(=3.54)$, coverage of the subject on time $(=3.55)$ and supporting instruction with teaching materials (3.89). As the value of grand mean $(=3.17)$ clearly indicated the students were not certain whether teachers were performing what they supposed to perform in the classrooms. From above discussion it is possible to conclude that it is difficult to say teachers so far have been performing to the best of their ability which is recognizable by their students. Therefore, the effectiveness of school leaders in study areas in question were not up to the level expected of them. For the main intention of this paper is to identify the effectiveness of school leader in examining the effectiveness of teacher performance, from what have been discussed it is possible to say that the competencies of the leaders in executing their duties need improvement 
Kebede, D. D., Demissie, E. B., \& Labiso, T. O. (2019). Study on Effectiveness of School Leaders in Primary Schools of Wolaita and Dawuro Zones in Southern Region of Ethiopia. Advances in Social Sciences Research Journal, 6(4) 245-255.

Table 3 Students responses on teachers' performance outside classroom activities

\begin{tabular}{|c|c|c|c|c|c|c|c|c|c|c|c|c|}
\hline \multirow[t]{3}{*}{ No } & \multirow{3}{*}{$\begin{array}{l}\text { Item describing conditions of } \\
\text { teacher performance }\end{array}$} & \multicolumn{11}{|c|}{ Alternatives } \\
\hline & & \multicolumn{2}{|c|}{ SA } & \multicolumn{2}{|c|}{$\mathrm{A}$} & \multicolumn{2}{|c|}{ UD } & \multicolumn{2}{|c|}{$\mathrm{D}$} & \multicolumn{2}{|c|}{ SD } & \multirow[t]{2}{*}{ Mean } \\
\hline & & $\mathrm{F}$ & $\%$ & $\mathrm{~F}$ & $\%$ & $F$ & $\%$ & $\mathrm{~F}$ & $\%$ & $\mathrm{~F}$ & $\%$ & \\
\hline 1 & $\begin{array}{l}\text { Support students to participate in } \\
\text { co curricular activities }\end{array}$ & 98 & 35 & 52 & 18.5 & 68 & 24.8 & 29 & 10.3 & 33 & 11.8 & 3.88 \\
\hline 2 & $\begin{array}{l}\text { Willing to support students outside } \\
\text { classroom }\end{array}$ & 97 & 34.7 & 55 & 19.8 & 65 & 23.3 & 34 & 12.2 & 28 & 10 & 3.96 \\
\hline 3 & $\begin{array}{l}\text { Respect the human and democratic } \\
\text { rights of the students }\end{array}$ & 189 & 67.5 & 68 & 24.3 & 23 & 8.2 & - & & - & - & 4.58 \\
\hline 4 & $\begin{array}{l}\text { Respect for school rules and } \\
\text { regulations }\end{array}$ & 166 & 59.3 & 53 & 18.9 & 42 & 18 & 13 & 4.6 & 6 & 2.14 & 4.28 \\
\hline 5 & $\begin{array}{l}\text { Works with other to create safe } \\
\text { and secure environment for } \\
\text { students }\end{array}$ & 81 & 28.7 & 92 & 32.6 & 20 & 6.9 & 81 & 29.4 & 6 & 2.4 & 3.65 \\
\hline 6 & $\begin{array}{l}\text { Promote tolerance and trust among } \\
\text { students }\end{array}$ & 80 & 28.6 & 90 & 32.5 & 18 & 6.8 & 82 & 29.6 & 8 & 2.5 & 3.54 \\
\hline 7 & Good relation with school leader & 37 & 13.2 & 51 & 18.2 & 103 & 36.8 & 62 & 22.1 & 27 & 9.6 & 3.03 \\
\hline 8 & $\begin{array}{l}\text { Presenting her/himself as a model } \\
\text { in action and character }\end{array}$ & 40 & 14.3 & 50 & 17.9 & 77 & 27.5 & 56 & 20 & 57 & 20.4 & 2.87 \\
\hline
\end{tabular}

4.50-5.00 $=$ strongly agree, 3.50-4.49= Agree, 2.5-3.49= Undecided 1.5-2.49= Disagree, $1.00-$ $1.49=$ strongly disagree

As we can see from the above table the respondents were strongly agree $(\mathrm{m}=4.58)$ on the issue that the teachers respect the human and democratic right of the students. Except the issue regarding whether teachers were a model in action and character $(m=2.87)$, in other activities outside the classroom respondents agreed that teachers performance was positive. The grand mean value $=3.72$ confirmed this fact. This indicates that teachers' performance in activities outside the classroom is good. Therefore, in this aspect the school leaders were effective.

In schools, one way of assessing teachers' performance is teachers' performance evaluation. Therefore, teachers' performance evaluation can be taken as a tool to measure the effectiveness of school leaders. 
Fig. 1 Level and percentage of teachers' performance evaluation

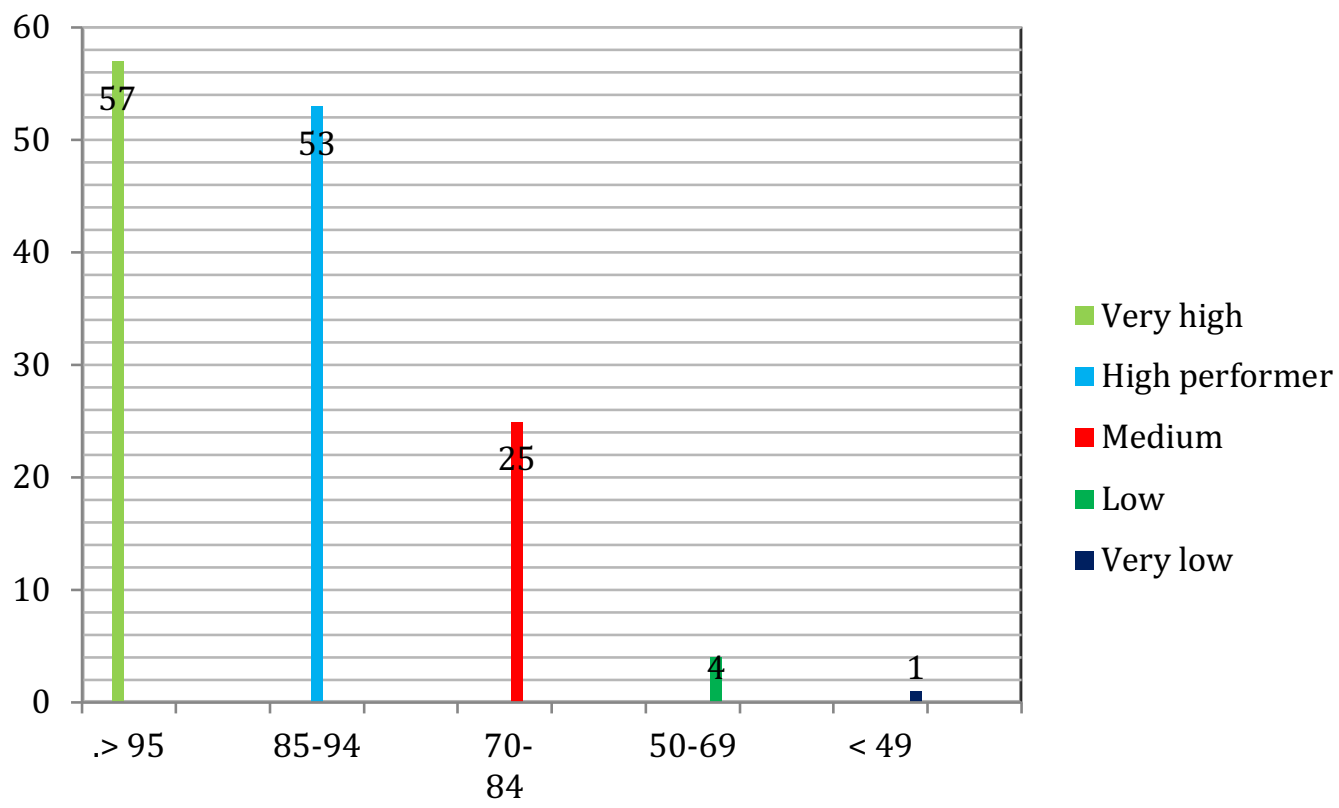

The table above makes it clear that almost 79\% (57) of the sampled teachers were high performer. Only 3\%of the teachers were identified as low performers. In earlier discussion students were reluctant and unable to decide whether teachers were effective in their performance or not. But here teachers' performance evaluation results tell as if the teachers were high performer. That means there is a gap between what the students said and the paperand-pencil results showed regarding teachers performance. Data from this we can say that teachers' evaluation results are not reliable indicator of performance in the schools in questions.

\section{THE EFFECTIVENESS OF SCHOOL LEADERS IN ENHANCING STUDENT LEARNING}

This part deals with the extent to which school leaders were working to ensure student learning which increase student performance 
Table 4 Response on leaders' effectiveness to enhance students' performance

\begin{tabular}{|c|c|c|c|c|c|c|c|c|}
\hline \multirow{3}{*}{ No } & \multirow{3}{*}{$\begin{array}{l}\text { Statements describes Leaders effort to } \\
\text { enhance student performance }\end{array}$} & \multicolumn{6}{|c|}{ Measures } & \multirow[t]{3}{*}{ Mean } \\
\hline & & \multicolumn{2}{|c|}{ High } & \multicolumn{2}{|c|}{ Medium } & \multicolumn{2}{|c|}{ Low } & \\
\hline & & $\mathbf{F}$ & $\%$ & $\mathbf{F}$ & $\%$ & $\mathbf{F}$ & $\%$ & \\
\hline 1 & $\begin{array}{l}\text { Leaders effort to make learners centered } \\
\text { dominant teaching methods }\end{array}$ & 67 & 24.5 & 164 & 58.5 & 49 & 17 & 3.14 \\
\hline 2 & Leaders effort to improve student outcome & 82 & 29.3 & 125 & 44.8 & 73 & 25.9 & 3.06 \\
\hline 3 & $\begin{array}{l}\text { effort made to get covered all missed } \\
\text { classes }\end{array}$ & 140 & 50 & 91 & 32.5 & 49 & 17.5 & 3.65 \\
\hline 4 & $\begin{array}{l}\text { relation made with parents and } \\
\text { community }\end{array}$ & 154 & 55 & 109 & 39.9 & 17 & 5.1 & 3.97 \\
\hline 5 & $\begin{array}{l}\text { effort made to get student engaged in } \\
\text { learning tasks }\end{array}$ & 60 & 21.4 & 94 & 33.6 & 126 & 45 & 2.52 \\
\hline 6 & $\begin{array}{l}\text { Leaders effort to maintain safe and } \\
\text { conducive environment for learning }\end{array}$ & 123 & 43.8 & 105 & 37.4 & 50 & 17.8 & 3.61 \\
\hline 7 & $\begin{array}{l}\text { Strength and support of co curricular } \\
\text { activities }\end{array}$ & 39 & 13.9 & 113 & 40.4 & 128 & 45.7 & 2.36 \\
\hline 8 & $\begin{array}{l}\text { Leaders effort to make teaching facilities } \\
\text { available on time }\end{array}$ & 80 & 28.6 & 117 & 41.8 & 83 & 29.6 & 2.94 \\
\hline 9 & $\begin{array}{l}\text { leaders ability to execute school program as } \\
\text { planned }\end{array}$ & 71 & 25.4 & 125 & 44.6 & 84 & 30 & 2.90 \\
\hline 10 & $\begin{array}{l}\text { Level of strength and implementation of } 1 \text { to } \\
5 \text { networking }\end{array}$ & 56 & 20 & 116 & 41.4 & 108 & 38.6 & 2.63 \\
\hline 11 & $\begin{array}{l}\text { Determination to reward students for their } \\
\text { achievement }\end{array}$ & 69 & 24.6 & 89 & 31.9 & 122 & 43.5 & 2.62 \\
\hline 12 & $\begin{array}{l}\text { Effort made to control cheating during } \\
\text { exam }\end{array}$ & 49 & 17.5 & 97 & 35 & 134 & 47.5 & 2.45 \\
\hline
\end{tabular}

\subsection{0-5.00 = High, 2.50-3.49= Medium, 1.00-2.49= strongly disagree}

The extent to which leaders accomplished their leadership can be used as a measure of their effectiveness. Students are among school community who best explain whether school leaders were effective in exercising their leadership role.

As we can see from the table, leaders effort was high in getting teachers cover missed classes $(\mathrm{m}=3.65)$, in relation made with parents and community $(\mathrm{m}=3.97)$ and in creating safe and conducive environment for learning $(\mathrm{m}=3.61)$. One of the item in which leaders effort critical was controlling cheating during examination $(m=2.45)$. The grand mean $=2.98$ shows that leaders performance was medium. This implies that the school leaders' effectiveness to enhance students learning is not as it supposed to be. In line with this the data obtained through interview also confirmed that the majority of the school leaders rated their performance medium. 
Fig.2 Grade eight result of students' from 2011-2013

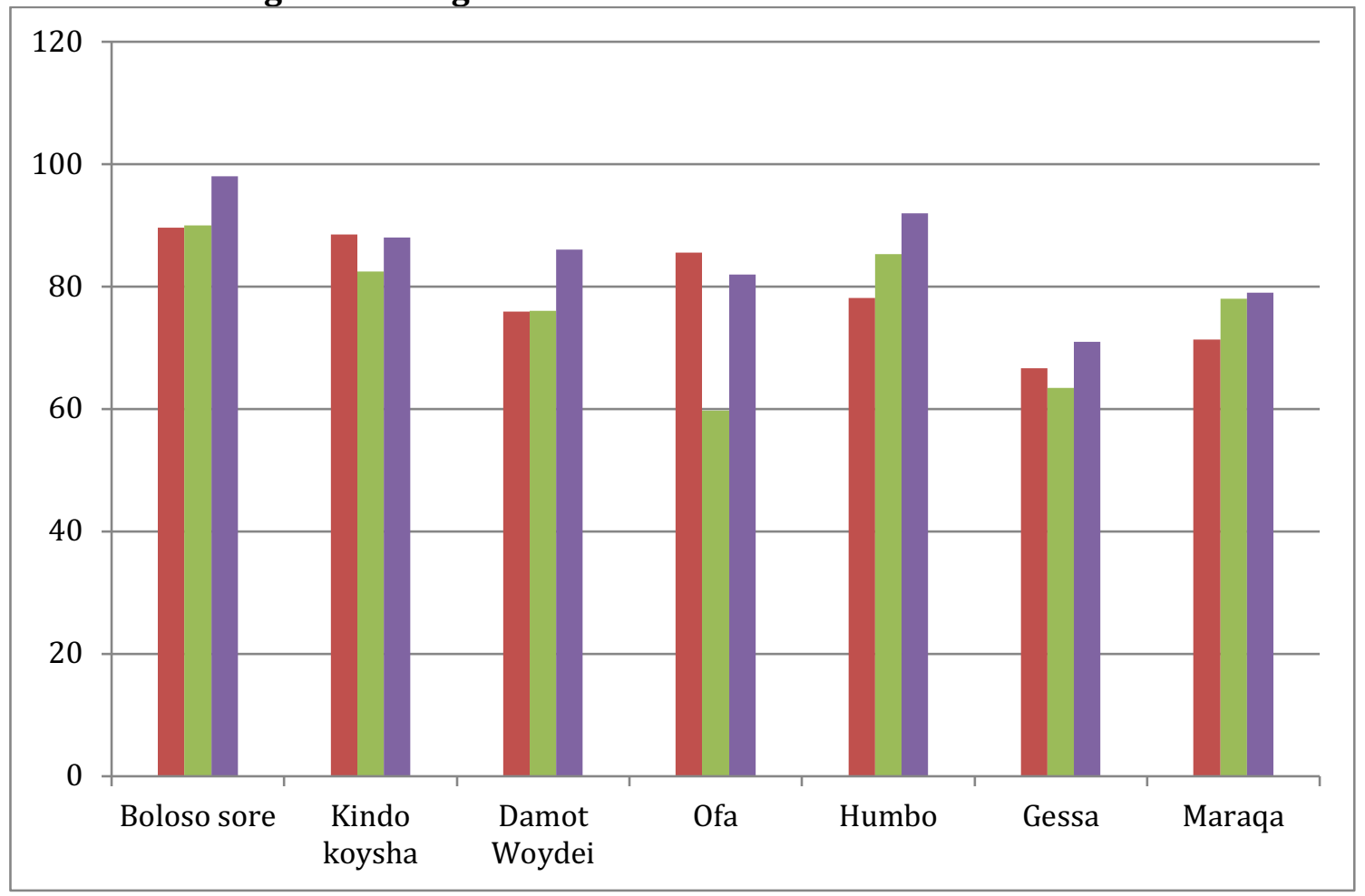

The achievement of students is one of the measures of effectiveness of school leadership. As the data displays the results do not show continuity, except two woredas (district), in improvement of student academic achievements. This abnormality in the result reflects the extent to which school leaders manage the schools so that the teachers' performance and student achievement would be determined. From this we can say that though the percentage of the student who passed in each academic years were high the achievement might not caused by the effort made by school leaders and teachers. This can be confirmed by item 12 of table 5 that the effort made by school leader to control cheating was low. Therefore the effectiveness of the school leaders is in question.

\section{BIBLIOGRAPHY}

Hallinger, P. 2007. The changing landscape of educational leadership development: A global perspective. Lisse: Swets \& Zeitlinger.

Harris, A., \& Hart, D. 2002. Teacher leadership: Principles and practices. A paper for The National College for School Leadership, Nottingham, England

Leithwood, K. \& Jantzi, D. 2007. Transformational leadership: Transformational leadership: International journal of educational management. (2),. No 2. Pp 109-123.

Ministry of Education. May 2011. Governing Guideline for the Implementation of the School Improvement Program, Revised; MOE, Addis Ababa.

Sarantakos, S.2005. Social research(3 ${ }^{\text {rd }}$ ed). Hampshire: Macmillan

Williams,P 2008. The New educational leaders: Changing leadership practice in an era of school reform. London: Paul Chapman Publishing

Wong ,C. \& Evers,W. 2002 Leadership for quality schooling: International perspective. Routledge. London. 